$\mathrm{Bij}$, S. van der, Verheij, R. Inzet variabiliseringsgelden 2013 leidt tot belangrijke verbetering EPD. SynthesHis: Tijdschrift voor Huisarts en Automatisering: 2013, 12(4), 16-17

\begin{tabular}{|l|l|}
\hline $\begin{array}{l}\text { Postprint } \\
\text { Version }\end{array}$ & 1.0 \\
\hline $\begin{array}{l}\text { Journal website } \\
\text { Pubmed link }\end{array}$ & https://link.springer.com/article/10.1007/s12494-013-0061-0 \\
\hline DOI & $10.1007 / \mathrm{s} 12494-013-0061-0$ \\
\hline
\end{tabular}

This is a NIVEL certified Post Print, more info at http://www.nivel.eu

\title{
Inzet variabiliseringsgelden 2013 leidt tot belangrijke verbetering EPD
}

\author{
SJOUKJE VAN DER BIJ (ONDERZOEKER NIVEL) EN ROBERT VERHEIJ (PROJECTLEIDER \\ NIVEL ZORGREGISTRATIE EERSTE LIJN)
}

\begin{abstract}
Om in aanmerking te komen voor de variabiliseringsgelden 2013 moeten huisartsen hun EPD op orde hebben. Dat betekent dat ze moeten registreren aan de hand van de richtlijn Adequate Dossiervorming met het EPD (ADEPD). Want als de kwaliteit van het registreren verbetert, nemen de risico's voor patiënten af.
\end{abstract}

Bijna alle huisartsen houden tegenwoordig elektronisch hun patiëntdossier (EPD) bij in een HIS. Ze doen dat echter niet allemaal volgens de richtlijn Adequate Dossiervorming met het EPD (ADEPD). Deze richtlijn, die het Nederlands Huisartsen Genootschap (NHG) hiervoor enkele jaren geleden ${ }_{1}$ heeft opgesteld, geeft aanwijzingen voor een goede, uniforme registratie. Zo moet er bijvoorbeeld bij ieder consult een diagnose of symptoom worden geregistreerd, dienen allergieën te worden bijgehouden en moet het medicatiedossier volledig zijn. Een complete, gestructureerde en uniforme registratie is cruciaal voor de kwaliteit van zorg en om de patiëntveiligheid te waarborgen. Een gestructureerd EPD helpt de huisarts om een goed overzicht te houden van de gezondheidstoestand van zijn eigen patiënten. Maar ook andere hulpverleners in de praktijk die bij de behandeling zijn betrokken, krijgen zo een goed overzicht van de gezondheidsproblemen van een patiënt. Bij de standaardberichten tussen de verschillende disciplines binnen de eerstelijnszorg wordt ook uitgegaan van een volgens de ADEPD-systematiek gestructureerd en ${ }_{2}$ gevuld EPD. Wanneer gegevens niet volledig of anderszins niet op orde zijn kan dit leiden tot meer risico's voor de patiënt.

\section{GEOORMERKTE GELDEN}

Mede daarom vormt in 2012 en 2013 de kwaliteit van dossiervorming de basis voor de verdeling van de variabiliseringsgelden. Deze 60 miljoen euro zijn geoormerkt om huisartsen voor bepaalde kwaliteitsinspanningen te belonen. Jaarlijks maken de zorgverzekeraars (Zorgverzekeraars Nederland) en de huisartsen-koepel LHV afspraken over de besteding van de variabiliseringsgelden. In 2012 en 2013 hebben zij ervoor gekozen ADEPD-registreren als basis te nemen voor de verdeling daarvan. In 2012 moesten praktijken al aangeven of ze bekend waren met de ADEPDrichtlijn. In 2013 moesten praktijken ook echt kunnen laten zien dat ze volgens de richtlijn registreerden. Daarbij is gekeken naar één specifiek aspect: het ICPCcoderen van de consulten. Huisartspraktijken moesten ten minste 70 procent van hun 
$\mathrm{Bij}$, S. van der, Verheij, R. Inzet variabiliseringsgelden 2013 leidt tot belangrijke verbetering EPD. SynthesHis: Tijdschrift voor Huisarts en Automatisering: 2013, 12(4), 16-17

consulten voorzien van een betekenisvolle ICPC-code om in aanmerking te komen voor de variabiliseringsgelden 2013. Beoogd wordt hiermee de kwaliteit van het registeren op een hoger plan te krijgen.

\section{METING VARIABILISERINGSGELDEN 2013}

Een belangrijk element in de ADEPDrichtlijn is dat de huisarts bij ieder consult een symptoom of diagnose registreert met behulp van een ICPC-code (International Classification of Primary Care). Voor de variabiliseringsgelden 2013 is daarom in iedere huisartsenpraktijk het percentage gedeclareerde consulten dat is voorzien van een betekenisvolle ICPC-code, vastgesteld.

Zowel ICPC-codes geregistreerd op een E-regel als in een aan het consult gekoppelde episode telden daarbij mee. ICPC-codes in de reeks 01-29 (symptomen) en 70-99 (diagnoses), A44 (inenting), R44 (influenzavaccinatie) en X37 (cervixuitstrijkje bevolkingsonderzoek) werden als betekenisvol aangemerkt. ICPCcodes A97 (geen ziekte) en A99 (andere gegeneraliseerde/ niet-gespecificeerde ziekte) waarbij de subcode ontbreekt, zijn natuurlijk wel eens van toepassing, maar zijn niet als betekenisvol meegerekend.

De metingen zijn gefaciliteerd door de leveranciers van de HISsen. Zij werden daarbij begeleid door het NIVEL, dat bij elk HIS controleerde of de berekeningswijze juist was. De berekening van het percentage consulten waarbij een ICPC-code werd geregistreerd, vond plaats in de huisartsenpraktijken.

Het resultaat, bestaande uit een teller en een noemer, kon door de praktijk naar het NIVEL worden gestuurd.

Bij een deel van de huisartsenpraktijken is ook een nulmeting uitgevoerd. Deze eerste meting betrof het laatste kwartaal van 2012 en was bedoeld om een praktijk inzicht te geven in de eigen score aan het begin van het jaar. Deelname aan de nulmeting was facultatief en niet noodzakelijk om in aanmerking te komen voor de variabiliseringsgelden.

Bij de tweede meting (de eindmeting) werd gemeten over de periode januari tot en met mei 2013. Deze meting moest duidelijk maken of praktijken voldeden aan het criterium voor de variabiliseringsgelden. Praktijken kwamen daarvoor in aanmerking als ze het resultaat van de eindmeting doorstuurden naar het NIVEL en minimaal 70 procent van de consulten voorzien was van een betekenisvolle ICPC-code. Ruim 4700 van de 5100 huisartspraktijken in Nederland hebben hun eindmeting bij het NIVEL aangeleverd.

Daarvan hadden 1650 ook een nulmeting aan het NIVEL gestuurd.

\section{EEN VERBETERING IN HET REGISTREREN?}

Bijna alle praktijken die hun scores voor de eindmeting instuurden (99,5 procent) registreerden bij meer dan 70 procent van de consulten een ICPC-code. Bijna 80 procent van de praktijken deed dat zelfs bij meer dan 90 procent van de consulten (tabel 1, kolom 4). Daarbij waren er weinig verschillen tussen de diverse HISsen. Van alle huisartsenpraktijken in Nederland stuurde 8 procent geen score in. Hoogstwaarschijnlijk zagen deze daar vanaf omdat ze beseften dat de score te laag was om voor de variabiliseringsgelden in aanmerking te komen.

Bij 1650 praktijken konden de nul- en eindmeting worden vergeleken (tabel 1, kolom 2 en 3). In die groep steeg het gemiddelde percentage consulten waarbij een betekenisvolle ICPC-code werd geregistreerd van 87 naar 97 procent. In absolute 
termen gaat het landelijk op jaarbasis naar schatting om 4,3 miljoen consulten waar vóór de inzet van de variabiliseringsgelden geen ICPC-code werd geregistreerd en na de inzet ervan wel. Bij de nulmeting voldeed 11 procent van de praktijken nog niet aan het criterium van 70 procent ICPC-codering. Bij de eindmeting was dat minder dan 1 procent. Het aantal praktijken met een score van meer dan 90 procent steeg van 64 naar 92 procent. Zowel bij aanvankelijk slecht registrerende als bij de goed registrerende praktijken was een verbetering zichtbaar, maar bij de eerste categorie was de verbetering het grootst.

Praktijken die bij de nulmeting 80 procent of lager scoorden hebben zich duidelijk verbeterd, gemiddeld met maar liefst 30 procentpunt.

\section{VOLHOUDEN}

De inzet van de variabiliseringsgelden heeft geleid tot een belangrijke verbetering in het vastleggen van een diagnose bij consulten in huisartsenpraktijken.

Zij zijn daarbij ook een beetje geholpen door de HIS-leveranciers, van wie sommigen het bijna onmogelijk maakten om géén ICPC-code vast te leggen, maar ook dit kan worden gezien als een gevolg van de inzet van de variabiliseringsgelden. HISleveranciers realiseerden zich dat een slechte score bij hun gebruikers gevolgen zou kunnen hebben voor hun marktaandeel. Zo sneed het mes aan twee kanten: zowel aan de kant van de huisartsen als aan die van de HISleveranciers.

Het effect van de variabiliseringsgelden moet echter ook weer niet worden overdreven.

Uit de nulmeting kwam immers naar voren dat een groot deel van de huisartsenpraktijken al goed registreerde vóór-dat er een financiële vergoeding tegenover werd gezet (ook al was in nulmeting een aantal HISsen oververtegenwoordigd waarin het ICPC-coderen in hoge mate wordt afgedwongen). Het is wel de vraag of huisartsen deze registratieverbetering blijven volhouden. En of ook de correctheid van de ICPC-codering is verbeterd. Bij kwaliteit van registreren gaat het er immers niet alleen om of de gegevens volledig zijn, maar ook of ze correct zijn. En hebben we in deze meting nog niet bekeken in hoeverre er ook in andere delen van het dossier een verbetering is opgetreden. Dit is voer voor nader onderzoek.

We kunnen echter constateren dat huisartsen en hun collega's in de praktijk nu een vollediger overzicht hebben van wat individuele patiënten mankeren en van de totale morbiditeit in hun praktijk. Ten tweede wordt beter voldaan aan een belangrijke voorwaarde voor gegevensuitwisseling tussen huisartsen en bijvoorbeeld huisartsenposten en voor het genereren van kwaliteitsinformatie uit routinematig door de huisarts vastgelegde gegevens. Ten slotte biedt deze verbetering van de registratie meer mogelijkheden voor onderzoek op basis van routinematig vastgelegde zorg-data.

\section{NOTEN}

1. Nederlandse Huisartsen Genootschap. Richtlijn Adequate dossiervorming met het Elektronisch Patiëntendossier. 2013.

2. Nederlandse Huisartsen Genootschap. Richtlijn Gegevensuitwisseling huisarts en Centrale Huisartsenpost (CHP). 2008. 
Bij, S. van der, Verheij, R. Inzet variabiliseringsgelden 2013 leidt tot belangrijke verbetering EPD. SynthesHis: Tijdschrift voor Huisarts en Automatisering: 2013, 12(4), 16-17

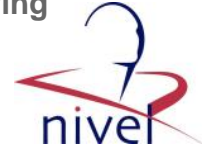

TABEL

Tabel 1. Het aantal praktijken uitgesplitst naar behaalde score op de nulmeting en eindmeting

\begin{tabular}{|c|c|c|c|}
\hline \multirow[b]{2}{*}{ Score } & \multicolumn{2}{|c|}{$\begin{array}{l}\text { Praktijken met zowel } \\
\text { nul- als eindmeting } \\
\qquad(n=1.650)\end{array}$} & \multirow[t]{2}{*}{$\begin{array}{l}\text { Alle praktijken met } \\
\text { een eindmeting } \\
(n=4.717)\end{array}$} \\
\hline & Nulmeting & Eindmeting & \\
\hline & n (\%) & n (\%) & n (\%) \\
\hline$<70 \%$ & $175(11)$ & $3(0)$ & $24(1)$ \\
\hline $70-80 \%$ & $134(8)$ & $21(1)$ & $234(5)$ \\
\hline $80-90 \%$ & $286(17)$ & $114(7)$ & $723(15)$ \\
\hline $90-100 \%$ & $1.055(64)$ & $1.512(92)$ & $3.736(79)$ \\
\hline Procent & 87 & 97 & 94 \\
\hline ICPC-registratie & & & \\
\hline gemiddeld & & & \\
\hline per praktijk & & & \\
\hline
\end{tabular}

